\title{
FINES PROVINCIAE
}

\section{JOHN RICHARDSON}

The notion of a frontier in the Roman world is capable, as the variety of papers contained in this collection demonstrates, of a wide spectrum of significance, meaning and context. My contribution to this feast is little more than an aperitif or (as I might hope) a bonne bouche, since I shall for the most part be looking only at the period of the Republic, and within that at a particular question or pair of questions. Those questions are not, however, insignificant nor, I hope, without interest. They are about the provinciae of Roman imperium-holders and of the Roman people, and, by extension, of the imperium populi Romani as a whole. My questions are: Did the provinciae and indeed the imperium have boundaries at all? And if so, what were they the boundaries of?

Of course, if we were to confine our attention to some of the most memorable statements in Latin literature, the answer to the first question would appear to be a simple 'No'. Famously writers in the late Republic described Rome's imperium as embracing the whole orbis terrarum. ${ }^{1}$ More famous still is the promise made by Jupiter in the first book of Vergil's Aeneid:

his ego nec metas rerum nec tempora pono: imperium sine fine dedi. ${ }^{2}$

But this answer may not be adequate for a serious response to the question. Quite apart from the tendency of such writers to make exaggerated claims, there is the matter of what it is that the word imperium is referring to; and, as I have tried to show in a book I have written recently, ${ }^{3}$ the predominant meaning of imperium down to the end of the Republic is not of a territorial empire but the power of the Roman magistrates and

\footnotetext{
${ }^{1}$ Rhetorica ad Herennium 4.13; Cicero, 2 In Verrem 5.168; Pro lege Manilia 53; De lege agraria 1.2; 2.15; 2.98: Pro Murena 74; Pro Sulla 33; Epistulae ad Atticum 1.19.7; De domo 75; Pro Sestio 67; 129; De oratore 3.131; De republica 3.24; Pro rege Deiotaro 15; Epistulae ad Atticum 14.5.2; De officiis 2.27; Philippicae 8.10; Cato minor, ORF 126.13; Anon., Bellum Alexandrinum 42.1-4; Nepos, Atticus 3.3.

2 Vergil, Aeneid 1.278-279.

${ }^{3}$ John Richardson, The Language of Empire: Rome and the Idea of Empire from the Third Century BC to the Second Century AD (Cambridge 2008).
} 
pro-magistrates and (by extension) of the Roman people. The boundaries, the frontiers of such power are somewhat different from those of a piece of land, however extensive.

In any case, the questions I have posed are in themselves ill-conceived. They imply that throughout the middle and late Republican period there was one answer. This is, to put it mildly, improbable. The provinciae of the time of Julius Caesar and Pompeius Magnus are very different from those during the Hannibalic war, and it is only to be expected that the boundaries, the fines and termini, of those two sets of provinciae will be different too. So, with those provisos, what can be said about fines provinciae in the last two centuries of the Republic?

I must begin with an observation that will not, I think, be a surprise to anyone, but whose ramifications have not always been noticed. It is clear that in the late third and second centuries $\mathrm{BC}$ a provincia was a task allotted by the senate to an individual holding imperium. This is apparent from the names of the provinciae which Livy gives in the notices of allocations which frequently appear at the beginning of consular years. Although such provinciae do often bear the name of a geographical area, this is not always the case: the allocations to the praetors who had charge of the courts in Rome occurs in the allocation lists as the provincia or iurisdictio urbana and peregrina.; ${ }^{4}$ and in other cases provinciae are called by the name of a people or of a task to be carried out, such as 'the fleet' or 'the war with Hannibal.' These are the names of responsibilities rather than areas, and the geographically named provinciae are no different: the provincia was a task, which might be defined in a variety of ways, one of which was the region within which the task was to be carried out. It is within this framework, this understanding at least by the senate of what a provincia was, that the development of the structures of the provinces of the Roman empire took place.

But were provinciae with geographical names geographically bounded? The model for such a definition of an area has been sought in the listings (formulae) which Aemilius Paullus drew up in his settlement of Macedonia in $167 . .^{6}$ The problem with this suggestion is that

\footnotetext{
${ }^{4}$ Livy 24.9.5; 25.3.1-2; 27.7.7-14; 27.22.2-7; 27.36.10-12; 29.13.1-3; 30.27.6-10; $32.28 .1-9 ; 33.26 .1-4 ; 33.43 .1-6 ; 34.43 .6-9 ; 35.20 .7-10 ; 37.2 .1-10 ; 40.44 .6 ; 41.8 .2-5$; 41.15.4-6; 42.1.5-6; 43.11.8; 45.44.2.

${ }^{5}$ Livy 27.22.2 ('Salelntini'); 44.1.3 ('classis'); 24.44 .1 ('bellum cum Hannibale').

6 A.W. Lintott, Imperium Romanum: Politics and Administration (London 1993), 2832.
} 
what Paullus was constructing was not a provincia, and there is no evidence for such a formula for communities under the control of a provincial governor at this date. ${ }^{7}$ It is true that the Romans kept an official list of their allies (formula sociorum), twice mentioned by Livy; ${ }^{8}$ and an inscription of $74 \mathrm{BC}$ refers to individuals being entered on a list of friends of the Roman people, ${ }^{9}$ which probably implies the existence of an official list of amici, both individual and corporate. Neither of these, however, provides evidence for a provincial formula in the second century BC.

There are, however, some indications that there were provincial boundaries of some sort (fines or termini provinciae) in the late third and second centuries BC. When in 215 the praetor Ap. Claudius in Sicily became anxious about the situation in Syracuse, whence he had had reports of the negotiations the new young king, Hieronymus, was conducting with the Carthaginians, he is said by Livy to have established all his forces on the boundary between the provincia and the kingdom; ${ }^{10}$ and when, in 213, Livy describes the allocation of provinciae, he records that of the two pro-magistrates in Sicily, M. Marcellus (the consul of the previous year) was allotted the territory which had previously been the kingdom of Hieronymus' grandfather, Hiero II, while P. Lentulus was to hold the 'old' provincia. ${ }^{11}$ Although the allocation of provinciae for the previous year is missing from Livy's account, it appears that this repeats the pattern of the end of 214 . In both these cases, Livy uses the word fines, and it seems clear that there was indeed a frontier at this point between the earlier provincia Sicilia and the Syracusan kingdom, which became itself a provincia once the Romans were engaged in warfare against the city. The other clear evidence of a provincial boundary in Livy's account of this period comes in 197, when for the first time two praetors were sent to the Spanish provinciae, M. Helvius to Hispania ulterior and C.

7 The earliest use of the term as a provincial listing that I know of is the note of Pliny the Elder (Naturalis Historia 3.37) that the emperor Galba added the Avantici to the formula of the provincia Narbonensis. By the early third century AD such a list appears to have existed for all provinciae.

${ }^{8}$ Livy $43.6 .10 ; 44.16 .7$.

${ }^{9}$ CIL 12, 588, 7 (= R.J. Sherk, Roman Documents from the Greek East (Baltimore 1969), 22, 12): [Uteique Q. Lutatius, M.] Aemilius cos. a(lter) a(mboque), s(ei) e(is) $v$ (ideretur), eos in ameicorum formulam referundos curarent.

${ }^{10}$ Livy 24.7.9: ipse adversus Syracusana consilia $\langle a d\rangle$ provinciae regnique fines omnia convertit praesidia.

${ }^{11}$ Livy 24.44.4: prorogata imperia provinciaeque, M. Claudio Sicilia finibus eis quibus regnum Hieronis fuisset, $\langle P$.$\rangle Lentulo propraetori provincia vetus.$ 
Sempronius Tuditanus to Hispania citerior. These men were ordered to fix the boundaries (terminare) of what was to be regarded as each of the two provinciae. ${ }^{12}$

Here are undoubtedly fines and termini of provinciae, and it is probable that in at least the last two of these instances such language was used in the official reports emanating from the senate; but, in view of the picture of what a provincia was which we have noted in Livy's accounts of their allocation, it is worth asking what these boundaries were meant to bound.

In the first passage, the boundary mentioned lies between the provincia to which the Romans had sent praetors since 227 and the kingdom over which Hiero II had ruled until his death. The territory of the king had been guaranteed to him in the treaty made with the Romans when in 263 he had come over to the Roman side in the early stages of the first Punic war, and this treaty had been renewed in $248 .{ }^{13}$ It was in the course of his attempt to get this treaty renewed with Hieronymus after the death of his grandfather that Ap. Claudius was confronted in 215 with the pro-Carthaginian stance of the young king. ${ }^{14}$ It seems highly probable that the limit to which Livy refers is therefore that which kept the holder of the provincia Sicilia from exercising his imperium within the territory of an ally whose lands had been assured to him by a full treaty. ${ }^{15}$ Under these circumstances a boundary between the two is hardly surprising. This was of course no longer the situation in 214 or 213 , by which time the boundary had become a dividing line between two provinciae. The same is true of the obligation placed on the praetors sent to the Spanish provinciae in 197, where Livy explicitly states that they were to delimit what was Hispania ulterior and what Hispania citerior. ${ }^{16}$ Moreover, although this demarcation seems to have made little or no difference to the military activities of the commanders in Spain, who over the next few years were frequently to be found fighting in what was properly the territory assigned to their colleagues, ${ }^{17}$ one incident shows that at least the senate saw this as a significant

12 Livy 32.28.11: et terminare iussi qua ulterior citeriorve provincia servaretur. The use of the verb servare, which usually means 'keep', 'save' or 'watch over', may seem odd here, but it is used in a similar sense by the elder Pliny (Naturalis Historia 3.56; 3.62 and 4.68). On this boundary, see J.S. Richardson, Hispaniae (Cambridge 1986), 77-78.

${ }_{13}$ Polybius 1.16.9; Didorus 23.4.1. On the renewal in 248, Zonaras 8.16.

${ }_{14}$ Polybius 7.3.1; 5.1; Livy 24.6.4.

15 F.W. Walbank, An Historical Commentary on Polybius I (Oxford 1957), 68-69, points out that this was technically a foedus aequum.

${ }^{16}$ Livy 32.28.11: et terminare iussi qua ulterior citeriorve provincia servaretur.

17 Richardson 1986, op. cit. (n. 12), 88-89; 96-98. 
boundary between the areas in which they might properly exercise their imperium. When M. Helvius, the praetor sent to Hispania ulterior in 197, eventually returned to Rome in 195, he claimed a triumph for a victory fought against the Celtiberians, as he proceeded from his provincia to the camp of the consul Cato, for which he had used troops provided by his successor as praetor in Hispania ulterior, Ap. Claudius Nero. ${ }^{18}$ The senate refused him a triumph, on the grounds that he had fought under someone else's auspices and in someone else's provincia, ${ }^{19}$ and instead allowed him the lesser celebration of an ovatio. Although Helvius still held proconsular imperium, ${ }^{20}$ his victory had been won in Hispania citerior and with forces under Nero's command. For the senate at least the boundary between the two provinciae was a live issue.

The common element which links these three passages from Livy is that in each case the boundary of the provincia sets a limit on exercise of power by the magistrate or pro-magistrate to whom it is allotted. This is also the import of one other more generalised passage in Livy which refers to the boundaries of provinciae. When in 207 the consul C. Claudius Nero, facing Hannibal in the south of Italy, gained intelligence of Hasdrubal's intention of marching south from Umbria to link up with his brother, he decided to join M. Livius Salinator in the north. Livy, describing Claudius' reasons for making this decision, states that the consul thought that this was not a moment at which a commander should be restrained by the usual conventions to the limits of his own provincia to fight with his own forces against the enemy prescribed by the senate. ${ }^{21}$ Once again, the fines of the provincia are boundaries on the exercise of the magistrates' imperium rather than the frontiers of an administrative area; and it is worth noticing that on this occasion the provinciae of the consuls, as given in Livy's account of the annual provincial allocations, were respectively 'against Hannibal, the Bruttii and Lucani' and 'Gallia against

18 Livy 34.10.1-7.

19 Livy 34.10.5: causa triumphi negandi senatui fuit quod alieno auspicio et in aliena provincia pugnasset. Compare the senate's reaction in 171 to the attempted incursion by the consul, C. Cassius Longinus, from the provincia Gallia into Macedonia, which was held by his colleague, P. Licinius Crassus: senatus indignari tantum consulem ausum, ut suam provinciam reliqueret, in alienam transiret (Livy 43.1.9).

20 As seen in the record of his ovatio in the Fasti Urbisalvienses (A. Degrassi, Inscriptiones. Italiae 13.1 (Rome 1947), 338).

21 Livy 23.47.7: tum Claudius non id tempus esse rei publicae ratus quo consiliis ordinariis provinciae suae quisque finibus per exercitus suos cum hoste destinato ab senatu bellum gereret. 
Hasdrubal, ${ }^{22}$ in both cases describing the area in which imperium was to be exercised and the task to be carried out.

The boundaries of provinciae at this stage of the Roman republic are of course geographical, but seem to be limitations on the use of the holder's imperium rather than of territory of the Roman empire. ${ }^{23}$ Good fences make good neighbours, as the New England farmer remarks in Robert Frost's poem $;{ }^{24}$ but in this case the neighbours on both sides of the fence appear to be Roman commanders, or a Roman and a treaty-based ally. That, after all, is what might be expected at a period when a provincia was seen as the task assigned by the senate to a holder of the essentially unrestricted power given to a magistrate or pro-magistrate, not least to avoid problematic clashes between two such imperia. It would appear that the boundaries of a provincia in the earlier second century вС were limits on the imperium of its holder.

To move forward, what was the situation in the first century? The obvious place to look is in the works of Cicero and his usage of the terms fines and termini with regard both to imperium and provincia. It is worth noticing in passing that, of course, there are other sorts of limits to imperium than territorial ones: the imperium of a magistrate or promagistrate had a chronological end, and the words finis and terminare are used by Cicero in this way. ${ }^{25}$ But to concentrate for the moment on imperium as the power of the Roman people, there are six passages where Cicero uses termini or terminare to speak about the limits (or more accurately the lack of limits) of the people's power, all but one from the period between 56 and 53 BC. ${ }^{26}$ Although these are undoubtedly about the bounds (or boundlessness) of the imperium, it is in most cases not easy to determine what it is that is (or rather, is not) bounded. It is worth noting, however, that the instance which appears at first sight the most territorial, where in the pro Balbo Cicero describes the walls of Gades as

${ }^{22}$ Livy 27.35.10: provinciae iis non permixtae regionibus, sicut superioribus annis, sed diversae extremis Italiae finibus, alteri adversus Hannibalem Bruttii et Lucani, alteri Gallia adversus Hasdrubalem quem iam Alpibus adpropinquare fama erat, decreta.

${ }^{23}$ That is not of course to say that the Romans had no concept of boundaries of other sorts. Polybius refers to limits on sailing in the first treaty with Carthage (3.22.5) and on the treaty with the Illyrians in $228 \mathrm{BC}(2.12 .5)$; and to limit Carthaginian military movements in the Ebro treaty (3.27.9). The word finis also occurs in a very early inscription from Samnium (ILLRP 7).

${ }^{24}$ R. Frost, 'Mending Wall', in The Poems of Robert Frost (New York 1946), 35-36.

252 In Verrem 5.77 (finis); Epistulae ad Familiares 3.12.4 (terminare).

263 In Catilinam 26; Pro Sestio 67; De provinciis consularibus 31; Pro Balbo 13; 39; Orationes perditae 15 (De aere alieno Milonis) fr. 10. 
having been set by the maiores as the bounds of imperium just as Hercules had used them as the limits of his labours and his journeys, the imperium in question is linked with the nomen of the Roman people, which suggests that imperium here is abstract (that is 'power') rather than territorial. ${ }^{27}$ In case of ines $^{28}$ it is still more difficult to determine whether the 'bounds' or the 'territories' of the power are being referred to since the word finis in the plural can have either of these meanings. ${ }^{29}$ In some cases it is clear that 'boundaries' is intended, because the word is used in connection with terminare $;^{30}$ in others, especially where the reference is to propagatio finium imperi, ${ }^{31}$ it is not clear which is intended (and indeed may not have been to Cicero). An interesting instance, which reveals precisely this ambiguity, is in pro Murena, where Cicero is contrasting the legal activity of the prosecutor, Ser. Sulpicius, with the military functions of Murena. 'Ille (that is Murena) exercitatus est in propagandis finibus, tuque (Sulpicius) in regendis. ${ }^{32}$ Here the fines are (at least in Sulpicius' case) clearly boundaries, since fines regere is a technical term for fixing the boundaries of fields and the like; ${ }^{33}$ but it would be rash to pretend on the basis of such a carefully ambiguous passage as this that the idea of fines propagare relates to boundaries rather than territory. What it does show, however, is that for Cicero and his hearers the ambiguity was a live one, and that the meaning of fines was not settled. For that very reason, it is not possible to know from such passages whether the meaning of fines imperi was for Cicero 'bounds on the power of the people' or 'territory of the Roman empire'; or even whether such a distinction would have made any sense to him.

It is interesting to note, however, that he rarely refers to the boundaries of provinciae, and only speaks of fines provinciae in one speech, that against L. Piso in 56. ${ }^{34}$ Here the same problem arises as with fines imperii

\footnotetext{
27 quorum moenia, delubra, agros ut Hercules itinerum ac laborum suorum, sic maiores nostri imperi ac nominis populi Romani terminos esse voluerunt (Pro Balbo 39).

283 In Catilinam 26; De provinciis consularibus 29; Pro Balbo 13; De republica 3.24; Pro Milone 98; Philippicae 13.14.

29 See OLD, s.v. finis (1) and (2).

303 In Catilinam 26; Pro Balbo 13.

31 De provinciis consularibus 29; De republica 3.24; Philippicae 13.14.

32 te gallorum, illum bucinarum cantus exsuscitat; tu actionem instituis, ille aciem instruit; tu caves ne tui consultores, ille ne urbes aut castra capiantur; ille tenet et scit ut hostium copiae, tu ut aquae pluviae arceantur; ille exercitatus est in propagandis finibus, tuque in regendis. (Pro Murena 22).

33 Compare Topica 23 and 43, and De legibus 1.55 for this usage.

34 In Pisonem 37; 38; 49; 57.
} 
as to whether it is the boundaries or the territory of the provincia which is being referred to, or even if the distinction is one which Cicero would have recognised. At one point he describes the fines of the provincia Macedonia as having in the past been the same as that of the swords and javelins of its commanders, ${ }^{35}$ which sounds as though it means 'boundaries'; but in the previous section he has upbraided Piso for having acquired by improper means a consularis provincia with fines limited only by his own cupidity, to which for the first time Achaea, Thessaly, Athens and indeed the whole of Greece had been attached. ${ }^{36}$ That sounds like an area or territory. In another passage the fines provinciae are said to have been as large as he could wish, which must surely mean 'territory'; but then in the same sentence Piso is described as not confining himself within these and bringing in an army from Syria, outside the provincia. ${ }^{37}$ Here, as with the fines imperii, there seems to be no sharp distinction between the two meanings of the word. Asinius Pollio, writing to Cicero in 43 , says that matters are so peaceful in Hispania ulterior that he has never gone outside the fines of his provincia, while Cicero, writing to the senate from Cilicia in 51, describes areas in which he was present with his army as fines Lycaoniae et Cappadociae. ${ }^{38}$

It is clear that for Cicero provincia could be used both of the responsibility of a magistrate or pro-magistrate and of a piece of territory for which such a person was responsible, even when the imperium-holder was not involved. This two-fold pattern can be seen, for instance, from a comparison of Cicero's remarks about the consuls of 58 , L. Piso and A. Gabinius, and about Caesar, following his victories in the Civil Wars. The former pair, whom he accuses of having been bought off by the tribune Clodius by being given desirable provinciae through the lex Clodia, he describes as 'traders in provinciae, and Clodius as selling provinciae. ${ }^{39}$ Here what is being bought and sold is the responsibility of the magistrate, not pieces of territory. On the other hand, he describes Caesar as being

35 In Pisonem 38: Macedoniam praesertim, quam tantae barbarorum gentes attingunt ut semper Macedonicis imperatoribus idem fines provinciae fuerint qui gladiorum atque pilorum.

36 In Pisonem 37.

37 In Pisonem 49: cum finis provinciae tantos haberet quantos voluerat, quantos optarat, quantos pretio mei capitis periculoque emerat, eis se tenere non potuit; exercitum eduxit ex Syria.

38 Asinius Pollio, apud Cicero, Epistulae ad Familiares 10.32.5; Cicero, Epistulae ad Familiares 15.1.2.

39 Post reditum ad Quirites 21; Post reditum ad senatum 10; Epistulae ad Familiares 1.9.13 (of Piso and Gabinius in 58); Pro Sestio 84 (of Clodius in 58). 
prepared to sell off provinciae and regiones alongside the possessions of individual citizens, where the items for sale are pieces of land. ${ }^{40}$

Despite the difficulty that we face in translating fines provinciae, and the infrequency of its use in Cicero, there is no doubt that he can use the word in a strongly geographical sense. For instance, the provincia Asia can be described as 'girded by the sea, adorned with ports, surrounded by islands', ${ }^{41}$ and in another place as 'girded by three new provinciae. ${ }^{42}$ Both these descriptions are of the land-mass that constituted the provincia, with no reference to any holder of imperium. Indeed, although in principle and in origin a provincia can only exist if there is a magistrate or pro-magistrate whose provincia it is, for Cicero it can also have an on-going existence in the absence of an imperium-holder. In a letter to Atticus, written as he returns from Cilicia in 50, Cicero complains that the senate has left provinciae 'sine imperio'; ${ }^{43}$ and in the de provinciis consularibus in 56, he describes Macedonia in the same terms when speaking of a time when it was controlled through legates. ${ }^{44}$ Mommsen believed that sine imperio was a technical term for the temporary absence of an imperium-holder, ${ }^{45}$ but whether this be true or not it does seem that there was a notion of an on-going entity which was still called a provincia when there was no specific individual whose provincia it was. Cicero in several places, when he is at pains to emphasise the history of Roman presence in an area, speaks in terms of the provincia passing from one magistrate to another in ways which demonstrate its continuity; ${ }^{46}$ and he mentions among the forgeries of Caesar's proposals which Antonius perpetrated after the assassination of the dictator, a decree that Crete should no longer be a provincia after the tenure of $\mathrm{M}$. Brutus as proconsul. ${ }^{47}$ If Cicero's understanding of what a provincia was had changed to include a more purely territorial sense than that which we have seen in Livy's account of the early second century, the meaning of the boundaries of a provincia will have expanded too.

40 De officiis 2.27: non singulorum civium bona publicaret, sed universas provincias regionesque uno calamitatis iure comprehenderet. Cf. Philippicae 5.11.

41 Pro Flacco 27: mari cincta, portibus distincta, insulis circumdata.

42 De provinciis consularibus 31: nunc tribus novis provinciis ipsa cingatur.

43 Epistulae ad Atticum 7.7.5.

44 De provinciis consularibus 5.

45 Th. Mommsen, Römisches Staatsrecht I (Leipzig 1887, 3rd ed.), 677 n. 3.

46 Divinatio in Caecilium 13; 2 In Verrem 1.16; 2.3; 2.5; 2.6; 2.7; 3.16; 3.125; 4.1; In Pisonem 44; 61; Pro Planco 28; Pro Scauro 26; Pro Ligario 2.

47 Philippicae 2.97. 
I have argued in my recent book that the major change in the ideas that the Romans had about their imperium and thus of the provinciae and their fines came about in the latter part of the reign of Augustus. ${ }^{48}$ The sense of the imperium as a territorial entity and of the provinciae as pieces of territory organised according to Roman norms, seem to have their roots in that period. It is then to be expected that the meanings of fines imperii and fines provinciae show consonant changes. In fact fines provinciae occurs rarely. Augustus in the Res Gestae claims to have increased the fines of all the provinciae of the Roman people which were closest to those nations which did not obey 'our imperium' (where imperium clearly still means 'power'); and here fines, while it could mean 'borders', sounds more like 'territory. ${ }^{49}$ Otherwise there are only four uses, two from Tacitus' Histories and one each from the elder Pliny and Suetonius, in Latin writers down to the mid-second century AD, and all relate to the boundaries of areas of Roman rule rather than limits on the power of its pro-magistrates. ${ }^{50}$

From late in the reign of Augustus, imperium acquired two new meanings. It refers to the office, the position of the emperor; and, in the phrase imperium Romanum, it means the 'Roman Empire.' This does not mean that the older ideas of imperium had disappeared. Throughout the period there are still references to the imperium of the Romans as encompassing the entire world.$^{51}$ There were also, however, recognitions of the existence of boundaries and limits to the extent of the imperium, whether temporary or permanent. ${ }^{52}$ In practice, as Tacitus knew well, the rivers

\footnotetext{
${ }^{48}$ Richardson 2008, op. cit. (n. 3), chapter 4.

49 Augustus, Res Gestae 26: Omnium provinc[iarum populi Romani], quibus finitimae fuerunt gentes quae $n[$ on parerent imperio nos] tro, fines auxi.

50 Tacitus, Historiae 1.51 (exercitus finibus provinciarum discernebantur); 2.12 (is concita gente (nec deest iuventus) arcere provinciae finibus Othonianos intendit); Pliny, Naturalis Historia 3.18 (Citerioris Hispaniae sicut conplurium provinciarum aliquantum vetus forma mutata est, utpote cum Pompeius Magnus tropaeis suis, quae statuebat in Pyrenaeo, DCCCLXVI oppida ab Alpibus ad fines Hispaniae ulterioris in dicionem ab se redacta testatus sit); Suetonius, Divus Julius 31.2 (consecutusque cohortis ad Rubiconem flumen, qui provinciae eius finis erat, paulum constitit).

${ }^{51}$ For instance: Velleius 2.131.1-2; Seneca, Dialogi 4.15.5; Silius Italicus 5.676; Suetonius, Divus Julius 61.1. On this, and the continuing belief in Rome's world-wide rule, see P.A. Brunt, 'Roman imperial illusions', in P.A. Brunt, Roman Imperial Themes (Oxford 1990), 433-48o. On the limits of this understanding, see C. Ando, Imperial Ideology and Provincial Loyalty in the Roman Empire (Berkeley-Los Angeles-London 2000), 320335.

52 termini imperii: Seneca, Dialogi 10.4.5; Naturales. quaestiones. 1.pr. 9; Pliny, Naturalis Historia 6.120; 7.117; Tacitus, Germania 29.3; Ann. 1.11. fines imperii: Seneca,
} 
which bounded the Germans to the west and south were frontiers, which the German tribes, unless they were especially favoured, could only pass unarmed and at a fee..$^{53}$ It is highly probable that boundaries such as Hadrian's Wall were intended to control the movement of those outside them into the empire. ${ }^{54}$ It does not, of course, follow that the Romans had no intention of moving beyond these lines, but it does suggest that there was an entity within them that might be called (as indeed it was now called) a Roman Empire.

By the time we have reached the first century AD, then, the boundaries, the fines, of the provinciae and of the imperium certainly exist, and what they bound are pieces of territory. But it was not ever thus. The change that I have sketched out in this paper, from limits on power and responsibility to lines on a map, marks a change; and the change, I would suggest, is not just one of language but of mentality, a change in what the Romans thought their empire was.

Durham, May 2009

Dialogi 12.10.3; Pliny, Naturalis Historia 12.19; Pliny, Panegyricus 54.4; Epistulae 8.6.6; Tacitus, Historiae 4.48; Juvenal 8.265.

53 Tacitus, Germania 41; Historiae 4.64.

${ }^{54}$ D.J. Breeze and B. Dobson, Hadrian's Wall (Harmondsworth 2000, 4th ed.), 15-16; $29-43$. 